\title{
A REVISTA BRASILEIRA DE GEOGRAFIA E SUA CONTRIBUIÇÃO AOS \\ ESTUDOS AGRÁRIOS NO BRASIL - 1940-2005
}

\author{
REVISTA BRASILEIRA DE GEOGRAFIA JOURNAL AND ITS \\ CONTRIBUTIONS TO THE AGRARIAN STUDIES IN BRAZIL (1940-2005)
}

\author{
Glaucio José Marafon \\ Professor Associado do Departamento de Geografia Humana - IGEOG \\ glauciomarafon@hotmail.com \\ Miguel Angelo Ribeiro \\ Professor Associado do Departamento de Geografia Humana - IGEOG \\ mamikisi@gmail.com
}

É dever de todo povo zelar por seus pensadores, por sua história e pelo conhecimento coletivamente construído, relembrando feitos capazes de influenciar as ações das gerações futuras (CASTRO, 2012, p. 20).

\section{Resumo:}

O objetivo deste trabalho é apresentar, de forma resumida, as ideias expostas pelos autores dos 65 textos selecionados na Revista Brasileira de Geografia. Tal intenção é de registrar, para cada período selecionado, a contribuição dos autores no tocante ao objetivo, metodologia e base conceitual utilizados, permitindo uma articulação entre os conteúdos dos respectivos artigos e as correntes do pensamento geográfico trabalhadas pelos mesmos. Posto isto, podemos afirmar que este exercício constitui uma importante contribuição ao estado da arte no campo dos estudos agrários no Brasil, e tal empreendimento tem como questão central: qual a contribuição dos autores e de seus artigos para os estudos agrários na geografia brasileira? Os artigos analisados contemplaram, tanto os estudos sobre interpretação e distribuição da produção e das propriedades rurais, como aqueles voltados para sistemas agrícolas, população rural, desenvolvimento agrícola, latifúndio e reforma agrária, modernização da agricultura, transformações técnicas e relações de trabalho, pequena produção agrícola, meio ambiente e modernização. Estes temas permearam os volumes da Revista Brasileira de Geografia, refletindo, em parte, as pesquisas dominantes referentes aos estudos agrários no Brasil, sendo que mais de $90,0 \%$ dos referidos trabalhos foram realizados por pesquisadores do próprio IBGE.

Palavras-chave: Revista Brasileira de Geografia. Estudos agrários. Geografia Agrária. 


\begin{abstract}
This paper aims to present shortly ideas by the authors of 65 texts selected from Revista Brasileira de Geografia journal. It intends to put into evidence for each chosen period their contributions as for aims, methodology and concepts they used, so that to articulate papers content with trends in geographical thought they work with. That said, we could state that such ideas presentation is important to the state of the art in the field of agrarian studies in Brazil because it focuses on the following question: what is the contribution of those authors and their papers to the agrarian studies in Brazilian geography. Selected papers comprise studies on interpretation and distribution of rural properties and production, agricultural systems, rural population, agrarian development, great landed estate and agrarian reform, modernization of agriculture, technical changes and labor relations, small agrarian output, environment, and modernization. These themes have permeated Revista Brasileira de Geografia volumes, which reflects partially predominant researches linked to the agrarian studies in Brazil. IBGE's researchers carried out more than 90 per cent of them.
\end{abstract}

Keywords: agrarian studies, Revista Brasileira de Geografia journal, agrarian geography

\title{
Introdução
}

O intento deste trabalho é apresentar, de forma resumida, as ideias expostas pelos autores dos 65 textos selecionados no periódico em tela. Tal intenção é de registrar, para cada período selecionado (MARAFON; RIBEIRO, 2012), a contribuição dos autores no tocante ao objetivo, metodologia e base conceitual utilizados, permitindo uma articulação entre os conteúdos dos respectivos artigos e as correntes do pensamento geográfico trabalhadas pelos mesmos.

A metodologia utilizada consistiu na seleção dos artigos e na separação dos mesmos, por períodos. Após a referida seleção, foi elaborado um resumo para cada artigo.

Cumpre fazer referência que os textos encontram-se ordenados segundo o ano de publicação no referido periódico. Posto isto, podemos afirmar que este exercício constitui uma importante contribuição ao estado da arte no campo dos estudos agrários no Brasil, e tal empreendimento tem como questão central: qual a contribuição dos autores e de seus artigos para os estudos agrários na geografia brasileira?

Os artigos analisados contemplaram, tanto os estudos sobre interpretação e distribuição da produção e das propriedades rurais, como aqueles voltados para sistemas agrícolas, população rural, desenvolvimento agrícola, latifúndio e reforma agrária, 
modernização da agricultura, transformações técnicas e relações de trabalho, pequena produção agrícola, meio ambiente e modernização. Estes temas permearam os volumes da Revista Brasileira de Geografia, refletindo, em parte, as pesquisas dominantes referentes aos estudos agrários no Brasil, sendo que mais de 90,0\% dos referidos trabalhos foram realizados por pesquisadores do próprio IBGE.

Tais artigos, além de retratarem o período em que foram escritos, fundamentados nas concepções teórico-conceituais vigentes, também apresentam escalas de análise que perpassam desde o âmbito nacional até o local.

Portanto, podemos afirmar que o periódico Revista Brasileira de Geografia, ao trazer contribuições de autores estrangeiros e nacionais, além daqueles vinculados à própria instituição (IBGE), assume grande importância, transformando-se em uma referência nacional. São autores que passaram por diferentes correntes do pensamento geográfico, desde aquelas pautadas nos estudos empírico/positivistas até as de cunho crítico, e contribuíram para fomentar a Geografia Brasileira.

O conhecimento interdisciplinar da Geografia permitiu que o referencial bibliográfico utilizado pelos autores em seus artigos, muitas vezes, não se limitasse somente a geógrafos. Bases conceituais de economistas, historiadores, sociólogos, antropólogos, entre outros, enriqueceram as pesquisas, em direção a um conhecimento transdisciplinar.

Cumpre ressaltar que o IBGE, através do órgão Conselho Nacional de Geografia (CNG), que daria origem ao novo IBGE, juntamente com os Conselhos de Estatística e Cartografia e Geodésia, e, mais tarde, Departamento de Geografia (atualmente Coordenação de Geografia), empregava um grande número de estudantes de Geografia, estagiários e pesquisadores, sendo os mais categorizados enviados para países estrangeiros para realizar aperfeiçoamento. Uma das consequências desse intercâmbio foi a contratação, como assistente técnico do IBGE, do geógrafo alemão Leo Waibel, que se encontrava nos Estados Unidos após a $2^{\mathrm{a}}$ guerra mundial, onde fora professor de alguns geógrafos do CNG. Sua contribuição está ligada a métodos e teorias alemães, provocando influência na forma como se conduzia a pesquisa em certas áreas. Waibel tinha preocupações teóricas que não eram comuns aos mestres franceses, como aquelas ligadas à análise espacial de Von Thünen, e encarava a paisagem mais por seus aspectos 
naturais, sobre os quais havia a influência do Homem, condicionado pela cultura de que era portador. Destaca-se sua obra "Capítulos de Geografia Tropical e do Brasil", contribuindo, principalmente, com a metodologia dos estudos agrários na geografia brasileira.

Além da contribuição desses autores para alimentar tais pesquisas, não podemos esquecer-nos das informações estatísticas e dos trabalhos de campo que foram utilizados, os quais contribuíram para o reconhecimento dos estudos agrários.

Portanto, este periódico, com outros, por sua sistematização e contribuição, permite traçar o estado da arte dos estudos agrários no Brasil. Muitas vezes, foi desprezado, diminuído e levado ao esquecimento, em decorrência da vinculação oficial da instituição ao Estado Brasileiro. Porém, na atualidade, tem sido reconhecido, por sua validade e importância. Podemos afirmar que o IBGE, com a Revista Brasileira de Geografia (RBG), contribuiu com uma parcela significativa da produção, para a geografia brasileira, dos estudos agrários.

Este reconhecimento encontra respaldo na trajetória da Revista Brasileira de Geografia, que está associada à própria trajetória da Geografia Brasileira, uma vez que, se os primeiros artigos eram descritivos, pautados em trabalhos de campo e na empiria, como reconhecimento do território, em outro momento, mais precisamente nos anos setenta, eram vinculados às análises estatísticas e matemáticas, verdadeiras produções em gabinetes. Enquanto, a partir dos anos 1980, as análises tornam-se mais interpretativas e críticas, utilizando-se de informações estatísticas e pesquisas de campo, procurando a compreensão da organização do espaço agrário brasileiro à luz de uma base conceitual que se aproximava da geografia crítica. Posto isto, não podemos deixar de reconhecer a importância desse periódico para a academia geográfica e para as instituições de pesquisa, uma vez que contribui para os estudos sobre o rural brasileiro, além de ser de relevância para a sociedade.

Após esta breve introdução, passemos aos resumos dos autores selecionados, por períodos analisados. 


\section{PRIMEIRO PERÍODO - 1940-1959}

\section{Ano II, nº 3, Julho de 1940, p. 349 - 370.}

Autor: Eng. Gileno Dé Carli (Chefe da Secção de Estudos Econômicos do Instituto do Açúcar e Álcool).

Título: Civilização do Açúcar no Brasil

$\mathrm{O}$ artigo trata de analisar, por meio da história econômica do Brasil, até onde o açúcar deu uma orientação em seus destinos, influenciando desde o momento em que a cana se localizou na costa nordestina, buscando um movimento intensivo espacial dos engenhos "banguês", na margem dos rios pernambucanos.

O autor preocupa-se também, a partir da influência da cana-de-açúcar e dos destinos econômicos e sociais nordestinos, em descrever como se fundou o regime das terras; a maneira por que se processou a formação do latifúndio, e principalmente daqueles latifúndios açucareiros. A luta entre os engenhos, e depois a luta tremenda entre a fábrica de açúcar e os engenhos "banguês", e mais recentemente da grande fábrica contra a pequena, foi apresentada pelo autor.

Dé Carli procura ainda abordar a produção açucareira, a partir do século XVIII, em São Paulo, comparando àquela do Nordeste.

\section{Ano IX, no 2, abril - junho de 1947, p. 159 - 184.}

Autor: T. Lynn Smith (Chefe dos Departamentos de Sociologia e Sociologia Rural da Universidade do Estado de Luisiana. Professor Visitante da Faculdade Nacional de Filosofia)

\section{Título: Sistemas Agrícolas}

O autor aponta, de início, a conexão existente ente o sistema agrícola de um povo e seu padrão de vida, optando pela análise a partir de três pontos de vista, a saber: (1) as reservas naturais disponíveis; (2) o trabalho executado pelo operário; e (3) a distribuição da população.

Smith afirma que o sistema agrícola utilizado por um determinado povo constitui um dos melhores índices de sua posição em escala social.

Em seguida, o autor descreve os sistemas agrícolas dos povos da Europa Meridional, exceção feita à França, além das áreas coloniais ocupadas pelos mesmos, comparando-os, e afirmando que, para estes, faltam certos elementos que muito contribuíram para o progresso da Europa setentrional e suas respectivas zonas de colonização.

O autor aponta que as diferenças entre os níveis de vida da Europa do Norte e a do Sul, e entre os países da América Anglo-saxônica e da América Latina, seriam provenientes de fatores culturais, e não raciais, nem climáticos. 
Mais adiante, enfatiza: sendo a hierarquia cultural profundamente arraigada, máximo na população rural e constituindo no Brasil "uma das nações mais rurais do mundo", explica-se a sobrevivência, entre nós, de um sistema agrícola deficiente e, para diminuir tal situação, restaria o recurso do empréstimo cultural, atuando através da educação e da imigração.

\section{Ano X, no 4, outubro - dezembro de 1948, p. 535 - 552.}

Autor: Afrânio de Carvalho (sem especificação)

Título: A Lei Agrária e a Geografia

O autor estuda os fundamentos da lei agrária, em projeto àquela época, e aponta que os fatores geográficos não foram considerados em sua elaboração.

Carvalho declara que o projeto considera as condições naturais não somente em relação ao estudo dos quadros regionais, como o objeto de conciliar as diferenciações locais, como também cuidou das prescrições estabelecidas, não se tornando inaplicável e ineficaz em virtude das particularidades das diferenças regionais.

Entre as lições que a Geografia Física e Humana oferecem ao legislador, destaca-se a conservação do solo, base de toda a vida sobre o mundo. O território brasileiro sofre, há muitos anos, os efeitos perniciosos da atividade destrutiva do homem sobre sua natureza e, particularmente, sobre seus solos, graças à agricultura itinerante, muito em prática aquela época, mencionando-se outros fatores de erosão, favorecidos pelo clima dos trópicos.

Assim, pode-se explicar, de certa maneira, a instabilidade de nossa agricultura e sua avidez de terras virgens. Com o fim de proteger interesses de tal importância, o autor aponta as providências que o projeto propõe, condenando práticas agrícolas que não devem ser aconselhadas e determinando certas medidas de cuidado e defesa, segundo as condições do terreno e da natureza da exploração.

\section{Ano XII, $n^{0}$ 1, janeiro - março de 1950, p. 73 - 88.}

Autor: Beatriz Célia Corrêa de Mello (Secção de Estudos do C.N.G.)

Título: Interpretação do Mapa de Produção de Café no Sudeste do Planalto Central do Brasil

$\mathrm{O}$ artigo tem por objetivo descrever, como aponta o título, o mapeamento da produção cafeeira no Sudeste do Planalto Central do Brasil, enfatizando o declínio de produção e sua expansão para a zona do Mato Grosso de Goiás, onde tem sido estimulado o cultivo e tem surgido novos núcleos produtores.

Utiliza dados estatísticos referentes às safras de 1920 e 1925. Caracteriza as condições da cultura cafeeira no Planalto Central.

O intuito do artigo é descrever a distribuição espacial do referido cultivo no recorte espacial selecionado, concluindo que o Planalto Central, de modo geral, Geo UERJ - Ano 14, nº. 23, v. 2, $2^{\circ}$ semestre de 2012 p. 552-587

ISSN: 1415-7543 E-ISSN: 1981-9021

http://www.e-publicacoes.uerj.br/index.php/geouerj 
apresenta condições adequadas à cultura cafeeira, em decorrência dos aspectos naturais que determinam tal distribuição.

\section{Ano V, no 37, abril - junho de 1950, p. 101 - 116.}

Autor: Ruth Matos Almeida Simões (Secção de Estudos do C.N.G.)

Título: Distribuição da Produção do Arroz no Sudeste do Planalto Central

O artigo tem por objetivo descrever, como aponta o título distribuição da produção de arroz no Sudeste do Planalto Central, enfatizando o declínio da produção e sua expansão para a zona do Mato Grosso de Goiás, onde tem sido estimulado o cultivo e tem surgido novos núcleos produtores.

Utiliza dados estatísticos referentes às safras de 1920 e 1925. Caracteriza as condições da cultura do arroz no Planalto Central.

O intuito do artigo é descrever a distribuição espacial do referido cultivo no recorte espacial selecionado, concluindo que o Planalto Central, de modo geral, apresenta condições adequadas à cultura de arroz, em decorrência dos aspectos naturais que determinam tal distribuição.

O Planalto Central apresenta características geográficas que o individualizam, e é a partir dessas características que podemos explicar a distribuição das densidades de produção de arroz, pois a cultura está relacionada com as características naturais: clima, solo, relevo, entre outros.

Apresenta a metodologia de confecção do referido mapa e a análise do mesmo, elaborando uma tipologia segundo as áreas de cultivo e de produção.

\section{Ano XII, no 3, julho - setembro de 1950, p. 3 - 20.}

Autor: Clarence Jones (Tradução de Silvio Fróis Abreu) - graduate School of North Western University - Illinois, U.S.A. - Consultor Técnico 1948. Visita a fazenda pela expedição do C.N.G. a Mato Grosso.

Título: A Fazenda Miranda a Mato Grosso

Como aponta Jones, a criação de gado para corte, há muito tempo, é uma atividade importante no sul de Mato Grosso. A fazenda Miranda, localizada quase no centro geográfico do continente sul americano, propriedade da Miranda Estancia and Company Ltd of London, é um exemplo das inúmeras grandes fazendas de gado nessa longínqua parte do Brasil.

Não é a única na região; há ali muitas fazendas que, do ponto de vista do caráter, da localização e da economia pastoril são mais ou menos semelhantes a ela.

$\mathrm{O}$ autor procura descrever o referido fixo segundo a atividade voltada à economia pastoril, ligada intimamente às condições físicas do local e das áreas vizinhas. 
Está ajustada não somente à natureza da terra, ao solo, clima, enchentes, fauna e flora, como também à sua localização nessa longínqua área do Brasil.

\section{Ano XII, no 3, julho - setembro de 1950, p. 21 - 31.}

Autor: Ruth Mattos Almeida Simões (Secção de Estudos do C.N.G.)

Título: Interpretação do Mapa de Produção de Cana-de açúcar no Sudeste do Planalto Central.

O artigo tem por objetivo descrever, como aponta o título, o mapeamento da produção de cana-de-açúcar no Sudeste do Planalto Central, enfatizando o declínio de produção e sua expansão para a zona do Mato Grosso de Goiás, onde tem sido estimulado o cultivo e tem surgido novos núcleos produtores.

Utiliza dados estatísticos referentes às safras de 1920 e 1925. Caracteriza as condições da cultura da cana-de-açúcar no Planalto Central.

O intuito do artigo é descrever a distribuição espacial do referido cultivo no recorte espacial selecionado, concluindo que o Planalto Central, de modo geral, apresenta condições adequadas à cultura de cana-de-açúcar, em decorrência dos aspectos naturais que determinam tal distribuição.

O Planalto Central apresenta características geográficas que o individualizam, e é a partir dessas características que podemos explicar a distribuição das densidades de produção de cana-de-açúcar, pois a cultura está relacionada com as características naturais: clima, solo, relevo, entre outros.

Descreve e interpreta o plantio de cana-de-açúcar no Planalto Central, apontando que as condições climáticas ótimas, atraentes para o plantio da cana, relacionam-se, nesta região, à alternância de estações marcadas quanto à distribuição das chuvas e à pequena amplitude anual de temperatura.

\section{Ano XIII, no 1, janeiro - março de 1951, p. 47 - 70.}

Autor: Elza Coelho de Sousa (Secção de Estudos Geográficos do C.N.G.)

Título: Distribuição das Propriedades Rurais no Estado de Minas Gerais (apresentado no XVI Congresso Internacional de Geografia Lisboa, abril de 1949).

$\mathrm{O}$ artigo tem como princípio norteador o estudo das propriedades rurais em Minas Gerais, a partir de uma apreciação de sua distribuição, segundo suas áreas médias em hectares.

Utiliza as informações do Recenseamento de 1940, as quais permitiram a elaboração de um mapa de área média de propriedade, pelo processo de isaritmas.

Como aponta a autora, para efeito do censo agrícola, foram considerados imóveis rurais os que se acham fora do perímetro urbano das cidades ou das vilas, e que 
se destinam à explotação direta do solo, seja para a produção de gêneros agrícolas, seja para a criação de gado.

Faz-se uma caracterização das propriedades rurais mineiras a partir das zonas, segundos seus aspectos físicos e humanos.

\section{Ano XIII, no 2, abril - junho de 1951, p. 117 - 124.}

Autor: Speridião Faissol (Divisão de Geografia - C.N.G.)

Título: A Fazenda Boa-Esperança (Goiás)

O objetivo principal do artigo, classificado como um comentário, era estudar principalmente problemas humanos e econômicos, a partir de uma série de viagens ao estado de Goiás, sendo indispensável à complementação destes estudos uma visita à fazenda Boa-Esperança, na região de Formosa, no Vale do Paraim.

A Fazenda Boa-Esperança é uma grande propriedade, com cerca de 25000 alqueires, de propriedade de uma companhia, a "Agro Colonizadora Industrial Ltda".

Seu estudo está atrelado aos métodos agrícolas utilizados na referida propriedade, pelo vulto do empreendimento e pelo que ela poderá representar como experiência e como realização no campo do aproveitamento de áreas semelhantes no Planalto Central Brasileiro. Posto isto, o seu estudo se torna bastante interessante, como apontou Faissol.

Interessante observar que o artigo trabalha conceitos clássicos de posição e sítio.

\section{Ano XIII, no 3, julho - setembro de 1951, p. 156 - 165.}

Autor: Ney Strauch (Divisão de Geografia do C.N.G.)

Título: Distribuição da População Rural de uma Parte do Sertão Nordestino

O trabalho, classificado como um comentário, procura analisar a distribuição da população rural, segundo os dados do Recenseamento de 1940, e sua distribuição corresponde à situação em 1948, tendo, por recorte espacial, parte do sertão nordestino.

Este recorte espacial tem por limites a bacia do São Francisco em Pernambuco, oeste de Alagoas e Sergipe, e parte do norte da Bahia. Este rio serve de eixo à dita região. O autor estabelece, na conclusão, uma relação entre o homem e o clima, para explicar a ocorrência espacial do respectivo fenômeno. O elemento natural é determinante para explicar tal distribuição, apesar de que o autor afirma que poderão ser modificadas através da ação governamental que visa a Bacia do São Francisco.

\section{Ano XIII, no 4, outubro - dezembro de 1951, p. 79 - 96.}

Autor: Eloísa de Carvalho (Divisão de Geografia do C.N.G.) 


\section{Título: O Trigo no Brasil}

O presente trabalho tem por fim demonstrar esquematicamente a situação da cultura do trigo no Brasil e examinar alguns fatores que podem contribuir para o seu desenvolvimento.

Para dar conta do objetivo proposto, o estudo foi conduzido sob o seguinte plano: I. Condições gerais de cultura; II. Produção - experiências realizadas; III. Conclusão.

Um mapa de distribuição da produção de trigo, elaborado pelo sistema de pontos, com valores de 1945, obtidos no Ministério da Agricultura, acompanha o texto. As informações estatísticas, como apontado, apresentam-se em nível municipal.

\section{Ano XIV, no 1, janeiro - março de 1952, p. 81 - 100.}

Autor: Inês Amélia Leal Teixeira Guerra (Divisão de Geografia do C.N.G.)

Título: O Cacau na Bahia

O artigo trata de descrever a distribuição da população de cacau na Bahia, além de analisar os aspectos econômicos e sociais da região cacaueira nesta unidade federada.

Como aponta Guerra, "o cacau é um dos grandes produtos da economia brasileira, devido a sua importância no mercado internacional, sendo o Brasil um dos primeiros produtores no mundo, apenas suplantado pela Costa do Ouro [...] foi, no entanto, no sul da Bahia, que o cacau encontrou ambiente mais favorável ao seu desenvolvimento e prosperou de modo definitivo, seguro e duradouro, contribuindo este estado com mais de $90 \%$ da produção total do Brasil".

\section{Ano XIV, no 2, abril - junho de 1952, p. 79 - 84 .}

Autor: Eloísa de Carvalho (Divisão de Geografia do C.N.G.)

Título: Densidade da População Rural no Sudeste do Planalto Central em 1940.

Artigo considerado como um comentário, enfatizando a distribuição da população rural a partir da variável densidade, tendo, como recorte espacial, o sudeste do Planalto Central em 1940.

Descreve a densidade, a partir das diferentes regiões encontradas no sudeste do Planalto Central, englobando porções do estado de Goiás.

A autora conclui o comentário afirmando que o estudo da distribuição da densidade de população rural no referido recorte espacial é resultado de dois fatores que influem poderosamente: a vegetação de matas, indícios de bons solos e a facilidade de transporte. 
14. Ano XIV, $n^{\circ} 2$, abril - junho de 1952, p. 85 - 88.

Autor: Elza Coelho de Sousa (Divisão de Geografia do C.N.G.)

Título: Distribuição das Propriedades Rurais no Sudeste do Planalto Central

O artigo, caracterizado como comentário, tem por objetivo analisar a distribuição das propriedades rurais no sudeste do Planalto Central e, como aponta a autora, a distribuição das propriedades rurais, neste recorte espacial, foi estudada de modo generalizado em um mapa, no qual se representou essa distribuição segundo as áreas médias das propriedades, por município. Como fonte de informação, foram utilizados os dados do recenseamento de 1940.

Para efeito do censo agrícola, foram considerados imóveis rurais os que se acham fora do perímetro urbano das cidades e vilas e que se destinam à explotação direta do solo, seja para a produção de gêneros agrícolas, seja para a criação de gado.

\section{Ano XIV, no 4, outubro - dezembro de 1952, p. 98 - 111.}

Autor: Ruth Mattos Almeida Simões (Geógrafo do C.N.G.)

Título: Produção de Uva no Rio Grande do Sul

$\mathrm{O}$ artigo trata de descrever e interpretar a distribuição da produção de uva no Rio Grande do Sul. Como aponta Simões, a viticultura alcança uma importância relativamente grande na economia da região, nesta unidade federada, hoje em dia, pelo desenvolvimento da indústria vinícola e aceitação geral do produto nos mercados nacionais.

Utiliza-se do mapeamento, com o objetivo de representar, de uma maneira esquemática, como se distribui a cultura da uva no Rio Grande do Sul, tomando por base as densidades de produção dos municípios. Utiliza-se a técnica do traçado de isarítmas, tendo por dados aqueles fornecidos pelo serviço de Estatística da Produção, do Ministério da Agricultura, correspondentes a 1946.

\section{Ano XVII, no 4, janeiro - março de 1955, p. 49 - 90.}

Autor: Orlando Valverde (Diretor da Divisão de Geografia do C.N.G.)

Título: O Uso da Terra no Leste da Paraíba (Tese apresentada no I Congresso Brasileiro de Geógrafos - AGB - Ribeirão Preto (SP), 1954).

Segundo o autor, o estudo está pautado em três elementos fundamentais: os trabalhos geográficos de equipe, executados sob os auspícios da AGB; os trabalhos de campo, com caráter de reconhecimento geográfico; além da interpretação de fotografias aéreas, de 1942.

A pesquisa, segundo Valverde, tem como objetivos caracterizar e representar cartograficamente os sistemas de utilização da terra e os regimes de propriedade em vigor no leste da Paraíba, apresentar sugestões para um planejamento rural na região

Geo UERJ - Ano 14, nº. 23, v. 2, $2^{\circ}$ semestre de 2012 p. $552-587$

ISSN: 1415-7543 E-ISSN: 1981-9021

http://www.e-publicacoes.uerj.br/index.php/geouerj 
estudada, além de realizar uma experimentação de método, qual seja o da interpretação de fotografias aéreas no sistema trimetrogon, para cartografar a utilização da terra.

\section{Ano XVII, no 7, julho - setembro de 1955, p. 95 - 106.}

Autor: Maria da Glória de Carvalho Campos (Geógrafo do C.N.G.)

Título: Notas para um Estudo da Distribuição do Rebanho Bovino no Brasil Meridional

Classificado como um comentário, tratando de caracterizar a pecuária como uma das principais atividades econômicas do sul do Brasil, utiliza-se de informações censitárias. Para tanto, analisa o mapa de distribuição do rebanho bovino no sul do país, destacando a importância do Rio Grande do Sul, comparativamente aos outros dois estados (Santa Catarina e Paraná), quanto ao plantel.

Apresenta a distribuição espacial do rebanho para a referida Região, além de caracterizar a industrialização da carne.

\section{Ano XIX, no 1, janeiro - março de 1957, p. 3 - 66.}

Autor: Speridião Faissol (Diretor da Divisão de Geografia do C.N.G.)

Título: O Problema do Desenvolvimento Agrícola do Sudeste do Planalto Central do Brasil (Tese aprovada para o grau de Doutor em Geografia, na Universidade de Syracuse - E.U.A.).

Tese resultante de pesquisas feitas pelo geógrafo no Centro-Oeste brasileiro, de 1946 a 1952, na região considerada como a mais desenvolvida do Centro-Oeste: o Planalto Central do Brasil.

Como aponta Faissol, ele o Planalto Central concentra mais da metade de toda a população da região e possui densa rede de transportes, estando localizadas nesta porção as áreas mais férteis do Centro-Oeste, dentro do raio de ação das ferrovias que vêm de São Paulo.

O trabalho teve a contribuição de Leo Waibel e Preston James.

O objetivo da pesquisa é o de fazer uma análise do problema do desenvolvimento agrícola do sudeste do Planalto Central do Brasil, através do uso de métodos de investigação geográfica, envolvendo o estudo de relações espaciais, bem como associações características de uso da terra e suas qualidades físicas.

Aponta sua utilização para os geógrafos, técnicos em agricultura e administradores, cujo interesse no problema pode ser teórico ou prático, contribuindo, além disso, para a teoria e metodologia, através da análise de áreas em diferentes graus de generalização; para os problemas práticos, ele procura trazer a compreensão dos processos e fatores que concorreram para a presente situação da agricultura e 
povoamento nesta área, bem como para esclarecimento dos verdadeiros aspectos a serem considerados no planejamento de medidas de amparo à região.

19. Ano XX, no 3, junho - setembro de 1958, p. 53 - 71.

Autor: Delinda Martinez Alonso (Geógrafo do C.N.G.)

Título: Aspectos Geográficos da Cultura Fumageira no Estado do Rio Grande do Sul Brasil (Tese apresentada ao XVIII Congresso Internacional de Geografia - Rio de Janeiro 1956)

O trabalho se propõe a analisar os aspectos geográficos e a distribuição da cultura fumageira no Estado do Rio Grande do Sul, a qual tornou-se importante atividade econômica rio-grandense; e sua industrialização, uma das maiores fontes de renda do Estado.

O artigo enfatiza as condições de cultura do ponto de vista climático, do solo, além da variedade escolhida e dos tratos culturais dedicados à planta; as zonas de maior produção, com os principais municípios produtores gaúchos.

A autora aponta em suas conclusões: "sobressai, assim, dentro do aspecto rural rio-grandense a paisagem fumageira - as inúmeras e pequenas lavouras, os galpões e as estufas, as fábricas - tudo isso nos revelando a importância econômica do cultivo da nicotianatabacum não só para o Rio Grande do Sul, como para o Brasil’”.

\section{Ano XXI, no 2, abril - junho de 1959, p. 3 - 22.}

Autor: Edgard Teixeira Leite (Sem nomeação de titulação)

Título: O Problema da Terra no Brasil. Latifúndios e Reforma Agrária. Medidas de Proteção ao Rurícola.

O artigo preocupa-se em analisar a questão da terra no Brasil, tendo como variáveis os latifúndios e a reforma agrária.

Na primeira parte, enfatiza o problema da terra no Brasil, associando a três aspectos fundamentais da economia: alimentação da população em pouca expansão demográfica; criação de um poderoso mercado interno; e promoção do equilíbrio entre massas campesinas e urbanas. Na segunda, expõe a Reforma Agrária, destacando: "numa hora em que se agita, sob o império das emoções e dos interesses, não raro puramente demagógicos, a bandeira da reforma agrária".

A reforma agrária, disse-o de forma lapidar o ministro João Cleofas, "é uma expressão muito vaga, muito usada, poucas vezes defendida, e talvez mesmo poucas vezes compreendida". 
21. Ano XXI, no 3, julho - setembro de 1959, p. 3 - 100 .

Autor: Pasquale Petrone

Título: A Região de São Luís do Paraitinga (Estudo de Geografia Humana)

O artigo descreve a área onde está localizada a cidade de São Luís do Paraitinga, pertencente à porção do território paulista comumente denominada de "Zona do Alto Paraíba”.

Neste contexto, aborda os aspectos naturais, enfatizando o relevo e a hidrografia; em seguida, trata do povoamento e da evolução da paisagem, priorizando a cobertura vegetal e o plantio do café. Na terceira parte, analisa a população e suas características. Seguem-se as partes IV - As Principais Atividades Rurais; V - Sistemas de Trabalho; VI - As Propriedades Rurais; VII - A Cidade de São Luís do Paraitinga.

\section{Ano XXI, no 3, julho - setembro de 1959, p. 127 - 152.}

Autor: Nilo Bernardes (Geógrafo do C.N.G. Sócio efetivo da A.G.B.)

Título: Notas sobre a Ocupação Humana da Montanha no Distrito Federal

Bernardes procura descrever e analisar, a partir da Palestra realizada em 29/08/1958 no Curso de Geografia Carioca, a ocupação humana da montanha no Distrito Federal, atualmente município do Rio de Janeiro. Primeiramente, apresenta os aspectos naturais e suas características - o relevo, o qual associa à utilização da terra; o clima; a vegetação secundária ou das culturas; o regime de propriedade; fases da vida rural; a paisagem cultural e o papel da circulação.

Conclui afirmando: "Não é exagero, então, dizer que a serra se torna agora o refúgio do pequeno agricultor do Distrito Federal".

\section{SEGUNDO PERÍODO - 1961-1969}

23. Ano XXIII, no 2, abril - junho de 1961, p. 103 - 160 .

Autor: Nilo Bernardes (Geógrafo do C.N.G.)

Título: Características Gerais da Agricultura Brasileira em Meados do Século XX.

O autor preocupa-se em analisar a preponderância que cabe às atividades agropecuárias no conjunto da economia brasileira e, deste modo, "o que mais importa é saber em que proporção este espaço ocupado está sendo convenientemente utilizado". Para maiores reflexões, sugere um exame da repartição das áreas das propriedades segundo os modos principais de utilização da terra. 
Apresenta o artigo dividido em quatro partes: 1. Características gerais da economia agropecuária; 2. A estrutura fundiária e o regime de exploração da terra; 3 . Matrizes das instituições agrárias; 4. Modo de utilização da terra (sistemas agrícolas).

24. Ano XXIII, no 3, julho - setembro de 1961, p. 3 - 40.

Autor: Orlando Valverde / Myriam G. C. Mesquita (Geógrafos)

Título: Geografia Agrária do Baixo Açu.

Como apontam os autores em nota, o presente trabalho é um exemplo de Geografia aplicada. Resultou de observações e inquéritos realizados na região em 1960, pelos autores, servindo de fundamento às pesquisas sobre hábitos alimentares, pela técnica de pesadas, efetuadas pela Missão Emma Reh, da FAO.

O artigo apresenta-se dividido em oito partes: 1. Resumo do Quadro Físico; 2. Ocupação da Terra; 3. O povoado de Santo Antônio; 4. Atividades Agropecuárias; [5. Fruticultura; 6. Outras culturas alimentares; 7. Pecuária; 8. Pesca]; 5. Abastecimento da cidade de Açu; 6; Quadro racial; 7. Perspectivas futuras; 8. Hábitos alimentares.

\section{Ano XXIV, no 4, outubro - dezembro de 1962, p. 3 - 41.}

Autor: Mário Lacerda de Melo

Título: Bases Geográficas dos Problemas do Nordeste

Este trabalho, tendo por finalidade o II Curso de Desenvolvimento Econômico,da SUDENE, preocupa-se em analisar o Nordeste como região natural e humana, tendo como recortes espaciais o úmido, o semi-úmido e o seco, retratando, em cada um deles, seus respectivos problemas.

\section{Ano XXV, no 3, julho - setembro de 1963, p. 57 - 86.}

Autor: Roberto Lobato Corrêa (sem especificação de título)

Título: Regime de Explotação da Terra no Nordeste. Uma temática de expressão cartográfica.

Como aponta Corrêa, "no estudo de Geografia agrária relativo a uma área, faz-se mister conhecer e interpretar a sua estrutura agrária, ou seja, o regime fundiário, o regime de explotação e a modalidade do tipo de cultivo. Essas relações entre o homem e a terra refletem a organização do espaço rural, organização na qual entram em jogo diversos fatores - fisícos, econômicos, históricos e culturais. Elas não são dissociadas, 
mas ao contrário cada uma depende da outra, formando uma trindade coesa e homogênea, que resulta na própria estrutura agrária" (p. 57).

O método de pesquisa empregado para a interpretação da estrutura agrária foi a partir do diagrama triangular, no qual, para cada município, são figuradas simultaneamente as porcentagens de assalariados, parceiros e não-remunerados. É esta distribuição dos elementos do regime de explotação que o autor procurará analisar, tendo como recorte o nordeste brasileiro.

\section{Ano XXVII, no 1, janeiro - março de 1965, p. 129 - 136.}

Autor: Antônio Teixeira Guerra (Geógrafo do C.N.G.)

Título: Os Solos e a Reforma Agrária no Brasil.

O artigo, classificado como comentários, foi realizado a partir da conferência pronunciada no Centro de Estudos Geográficos da Faculdade Fluminense de Filosofia. Como aponta o autor, a temática é bastante complexa.

Guerra explicita que o mesmo será analisado pela posição do técnico, no que diz respeito ao fornecimento de informações importantes para os políticos empenhados na campanha da reforma agrária. "Ela tem dado margem a debates acalorados entre os políticos, não se vendo serenidade nas análises" (p. 129). Além do mais, o assunto já caminhou para o campo das disputas pessoais, sendo encarado de acordo com a posição ideológica de cada um.

Uma primeira questão considerada por Guerra: Que se pensa conseguir com a reforma agrária? Secundada por: Qual o tamanho ideal da propriedade para ser explorada por uma família no estado de Pernambuco ou em São Paulo? É o caminho pretendido para dar conta da temática proposta.

Em suas conclusões aponta: "a reforma agrária entre nós não pode deixar de considerar, em lugar de destaque, a profunda desigualdade existente nas estruturas sócio-econômicas das diferentes regiões brasileiras" (p. 136). [...] prosseguindo, menciona: "Daí dizer-se que não existe no Brasil um problema agrário, pois há tantos quantos forem as áreas individualizadas segundo as estruturas sócio-econômicas encontradas" (p. 136).

\section{Ano XXVIII, no 4, outubro - dezembro de 1966, p. 3 - 34.}

Autor: Bertha K. Becker

Título: Expansão do Mercado Urbano e Transformação da Economia Pastoril (Estudo apresentado ao II Congresso Brasileiro de Geógrafos, Rio de Janeiro, 1965, pela Equipe do Centro de Pesquisas de Geografia do Brasil. Faculdade de Filosofia da UB, sob a coordenação da autora). 
O artigo tem por problematização a expansão da civilização urbano-industrial, correspondendo a uma verdadeira revolução alimentar em que assumem capital importância os produtos de origem animal.

Como expõe Becker, "observa-se que a cada elevação da renda per capita, registra-se imediata repercussão sobre o mercado de proteína animal, de sorte que o consumo de carne por habitante/ano é, hoje, um índice bastante expressivo do grau de urbanização e industrialização de um país" (p. 3).

Posto isto, o propósito do trabalho é verificar em que medida a nova sociedade industrial e urbana vem atingindo a velha organização rural brasileira, justamente num dos setores mais tradicionais da economia agrária - a pecuária; e aquilatar o grau e as formas da transformação do campo por irradiação urbana, através do estudo do processo de integração e organização da economia pastoril, tendo por recorte espacial o nordeste de Minas Gerais, em função do crescimento do mercado do Rio de Janeiro.

\section{Ano 30, n $^{\circ}$, abril - junho de 1968, p. 21 - 55.}

Autor: Gérard Prost.

Título: O Cariri Semi-árido Transformado pela Agave.

$\mathrm{O}$ artigo inicia uma série de estudos regionais relativos ao Estado da Paraíba e, neste sentido, tentando definir a originalidade de tal área-limite, o autor se propôs a estudar duas faixas contínuas representativas desses meios contrastantes: a primeira, no agreste, a leste do centro urbano de Pocinhos; e a segunda, de mais ou menos 50km², a noroeste deste centro, situada no Cariri. Esta última faixa é o objeto do presente artigo.

Para dar conta desta anlise, o artigo estruturou-se em: I. A Propriedade; II. A Economia Agrícola; III. Os Homens; IV. Conclusão: as situações sócio-econômicas.

\section{Ano 30, no 3, julho - setembro de 1968, p. 11 - 38.}

Autor: Gérard Prost.

Título: O Agreste de Esperança. A Fronteira Cariri - Agreste de Esperança.

Prost inicia seu artigo afirmando que o Agreste de Esperança contrasta fortemente com as regiões que lhe são vizinhas e seus limites são, portanto, bem definidos.

Em seu conjunto, o Agreste aparece como uma verdadeira campagne, como a concebem os europeus, na expressão do autor. Caracterizado por área totalmente humanizada pelos camponeses, o que é um fato raro no Brasil. Talvez a principal diferença que o distingue das áreas rurais do Velho Mundo é a sua ocupação recente: a paisagem atual do agreste é obra do homem nos últimos 40 anos.

Tentando detalhar um pouco mais esta hipótese de trabalho, examinaremos os aspectos dessa agricultura cuidadosa, e tentaremos um esboço das situações sóciodemográficas da área.

Geo UERJ - Ano 14, no. 23, v. 2, $2^{\circ}$ semestre de 2012 p. 552-587

ISSN: 1415-7543 E-ISSN: 1981-9021

http://www.e-publicacoes.uerj.br/index.php/geouerj 
31. Ano 31, no 1, janeiro - março de 1969, p. 3 - 102.

Autor: Maria Novais Pinto

Título: Contribuição ao Estudo da Influência da Lavoura Especulativa do Sisal no Estado da Bahia.

O artigo procura analisar a influência da lavoura especulativa do sisal no Estado da Bahia, tendo por recorte espacial a organização administrativa, pois todo o município se ressente, direta ou indiretamente, do sucesso e das crises do sisal. A escolha da autora para os municípios está associada àqueles propriamente produtores do referido cultivo, bem como aqueles que os envolvem, e onde essa atividade se apresenta em proporções consideráveis, a ponto de formar regiões sisaleiras secundárias.

Quanto à operacionalização, foram realizados inquéritos a partir de sondagens de opinião e de um questionário aplicado para quarenta estabelecimentos; além de informações estatísticas fornecidas pelos organismos oficiais, como recenseamentos gerais do país, relatórios de viajem de geógrafos do Conselho Nacional de Geografia (IBGE), bem como o relatório da excursão realizada pelo Laboratório de Geomorfologia e Estudos Regionais da Universidade da Bahia e dos inquéritos realizados pela Inspetoria Regional de Estatística do IBGE.

\section{TERCEIRO PERÍODO - 1971-1988}

\section{Ano 33, no 1, janeiro - março de 1971, p. 39 - 83.}

Autor: Raymond Pébayle (Assistente de Pesquisas do Centre d' Etudes de Géographie Tropicale Bordeaux, França)

Título: A Área Rural do Distrito Federal Brasileiro

No Distrito Federal brasileiro, a nova capital, Brasília, é uma espetacular manifestação de urbanismo, ao lado de um plano de aproveitamento sistemático de 5814 quilômetros quadrados de campos cerrados.

Como aponta Pébayle, "de fato, a partir de 1956, data oficial de sua criação, esta pequena porção de território passou por uma série de transformações que deviam, não somente criar uma rede de cidades satélites em torno dela, mas também modificar profundamente as áreas rurais vizinhas" (p.39).

Neste contexto, encontramos, hoje, nesta zona do Distrito Federal, um contraste equivalente ao que, no domínio urbano, opõe a Brasília oficial à antiga cidade livre, atual Núcleo Bandeirante. De fato, uma zona rural espontânea, praticamente não 
prevista pelos legisladores, e consequência de um enorme afluxo de população, desenvolveu-se ao lado da zona rural oficial.

Para tratar da referida temática, o autor dividiu o texto em duas partes: I. Uma área rural dirigida; II. Uma área rural espontânea.

\section{Ano 33, no 1, janeiro - março de 1971, p. 123 - 140.}

Autor: José Alexandre Felizola Diniz (Doutor do Departamento de Geografia da Faculdade de Filosofia, Ciências e Letras de Rio Claro, SP); Lúcia Helena Baptista de Oliveira (Bolsista da Fundação de Amparo à Pesquisa do Estado de São Paulo, junto ao Departamento de Geografia de Rio Claro).

Título: O Emprego de Modelos na Análise da Distribuição da Terra e das Categorias Dimensionais de Estabelecimentos Agrícolas no Leste do Estado de São Paulo.

Como registram os autores, "o presente trabalho foi iniciado em 1969 com o aproveitamento parcial de dados coletados para uma tipologia da agricultura, na Depressão Periférica Paulista, e outros obtidos para o restante da área estudada, desde o litoral até o contato com a depressão, totalizando 172 municípios" (p.123).

Utilizou-se, como fonte, os dados fornecidos pelo Censo Agrícola de 1960, para analisar a distribuição da terra e as categorias dimensionais das propriedades ou estabelecimentos agrícolas. Variáveis estas, de destaque na Geografia Agrária, constituindo-se em um dos pontos básicos da Estrutura Agrária que, por sua vez, é suporte à organização agrária, utilizando-se como método. O emprego de métodos quantitativos e de modelos, permite, como enfatizam os autores, uma globalização da distribuição da terra com as categorias dimensionais.

\section{Ano 33, no 1, janeiro - março de 1971, p. 137 - 147.}

Autor: Jorge Soares Marques

Título: Estrutura Agrária do Estado de Pernambuco

Em 1960, no Estado de Pernambuco, 259.723 estabelecimentos rurais ocupavam 5.924.630 hectares, o que representava, aproximadamente ${ }_{2} 60,0 \%$ da área total do Estado.

Neste contexto, utilizando-se dos métodos estatísticos e matemáticos, Marques procura analisar a concentração fundiária em Pernambuco, tendo por base a curva de Lorenz, considerando-se as informações obtidas no Censo Agrícola de 1960 do IBGE; além das formas de utilização da terra, modalidades de exploração agrícola (condições do responsável), e pessoal ocupado por estabelecimentos.

35. Ano 35, no 2, abril - julho de 1973, p. 135 - 143.

Autor: Elza Coelho de Souza Keller (Geógrafa do IBGE)

Geo UERJ - Ano 14, no. 23, v. 2, $2^{\circ}$ semestre de 2012 p. $552-587$

ISSN: 1415-7543 E-ISSN: 1981-9021

http://www.e-publicacoes.uerj.br/index.php/geouerj 
Título: Diretrizes e Prioridades das Pesquisas Agrárias (Documento apresentado à II CONFEGE)

Assim a autora registra o objetivo do artigo:: "dentro do vasto campo das pesquisas agrárias propomos como tema de estudo prioritário a classificação dos tipos de agricultura no Brasil e a definição das regiões agrícolas no espaço nacional, noções completas e sintéticas de grande importância científica e prática" (p. 135).

Embora o enfoque sintético dos problemas espaciais da agricultura seja tão antigo quanto a própria Geografia Agrária, vem-se verificando, nas últimas décadas, um grande desenvolvimento dos estudos referentes a sistemas agrícolas, sistemas de combinação de culturas, sistemas de utilização da terra, sistemas de criação de gado, tipos de agricultura, regiões agrícolas etc, realizados em diferentes escalas (mundial, nacional, regional, local) com metodologias as mais diversas.

Por outro lado, como aponta Keller, "a Geografia, atualmente por sua renovação filosófico-metodológica, não tem mais seu interesse centrado sobre a simples localização e descrição dos fatos geográficos, porém tem a preocupação básica de identificar e explicar estruturas e processos espaciais" (p. 135), alicerçados no desenvolvimento das técnicas matemático-estatísticas que possibilitam estruturar a ciência geográfica em termos de teorias e leis.

Por fim, na conclusão, dentre as muitas ideias expostas, a autora menciona que "a tipologia e a regionalização agrícolas são fundamentais a um desenvolvimento planificado da agricultura" (p. 142) e que "o planejamento do desenvolvimento agrícola pretende estabelecer, na base de premissas científicas, os tipos e as regiões agrícolas mais desejáveis, através da previsão e mudanças das características básicas da agricultura existente" (p. 142).

\section{Ano 36, no 1, janeiro - março de 1974, p. 33 - 52.}

Autor: Rivaldo Pinto de Gusmão (Geógrafo do IBGE).

Título: Estudo da Organização Agrária da Região Sul através de uma Análise Fatorial.

Como indica Gusmão, "o estudo da organização agrária da região sul do Brasil, com base nas suas características internas, sociais e econômicas foi efetuado através de uma análise fatorial complementada pela análise de grupamento" (p. 33). Sendo assim, o objetivo do referido estudo foi definir as principais linhas de diferenciação da organização agrária regional, bem como identificar os grupos de unidades observacionais que apresentaram características similares na atividade agrária, com relação aos aspectos considerados.

Para dar conta do objetivo proposto, foram utilizados dados de valor da produção de lavouras e rebanhos do ETEA (Ministério da Agricultura), e alguns índices estabelecidos com base nos dados preliminares gerais do censo agropecuário da região sul e do censo demográfico de 1970. As unidades de observação escolhidas foram as 64 microrregiões gaúchas, examinadas através de 35 variáveis e transformadas em sete fatores.

Geo UERJ - Ano 14, no. 23, v. 2, $2^{\circ}$ semestre de 2012 p. $552-587$

ISSN: 1415-7543 E-ISSN: 1981-9021

http://www.e-publicacoes.uerj.br/index.php/geouerj 


\section{Ano 39, no 2, abril - junho de 1977, p. 41 - 98.}

Autor: Lucy A. da R. Freire; Maria Therezinha de S. Soares e Marlene P. V. Teixeira (Setor de Geografia Humana do Instituto de Geociências - UFRJ, patrocinado pelo Conselho de Pesquisas da UFRJ).

Título: Organização Espacial da Agricultura no Estado do Rio de Janeiro.

$\mathrm{O}$ artigo tem por objetivo, segundo a sua problematização, o estudo da organização espacial da agricultura, através da análise quantitativa e comparativa da criação e das culturas, consideradas separadamente, por meio de índices; e integradamente, através de uma regionalização agrícola e do uso de modelos, sendo fundamental para sua compreensão, assim como para qualquer política de planejamento.

Para dar conta do objetivo, a pesquisa encontra-se estruturada em três partes. $\mathrm{Na}$ primeira, analisa-se os conceitos utilizados, delimita-se a área de estudo e faz-se a análise crítica dos dados. Na segunda parte, através de técnicas quantitativas, é feita uma análise das culturas agrícolas e da criação animal, permitindo a avaliação da diversificação, concentração e combinação de cada uma das atividades.

Por fim, na última parte, chega-se à regionalização, isto é, à descrição da organização espacial da agricultura fluminense.

\section{Ano 39, no 4, outubro - dezembro de 1977, p. 3 - 65.}

Autor: Olindina Vianna Mesquita; Rivaldo Pinto de Gusmão e Solange Tietzmann Silva (Geógrafos do IBGE. Departamento de Geografia).

Título: Modernização da Agricultura Brasileira.

O intuito da pesquisa é analisar a aplicabilidade dos conceitos de desenvolvimento rural, desenvolvimento agrário e modernização agrária, apresentandoos em níveis decrescentes de abrangência., Portanto, há grupos diferentes de indicadores para esses conceitos, possibilitando, assim, efetuar análises, em separado, dessas linhas de abordagem ao estudo da agricultura.

Como indicam os autores (p. 4), "neste estudo o interesse será essencialmente fixado na modernização agrária, constituindo parte de um estudo de caráter mais amplo, onde será analisado o desenvolvimento rural no Brasil. A ausência de estudos geográficos sobre desenvolvimento rural e a carência de suporte teórico para esse estudo global, confere-lhe um sentido exploratório e justifica que se busque isolar linhas de diferenciação quanto aos aspectos técnico-econômicos e sociais embutidos no conceito permanente de desenvolvimento rural".

Para dar conta do objetivo proposto, foram utilizados indicadores extraídos do Censo Agropecuário de 1970, que possibilitem aferir a participação do capital no processo de produção, sendo aplicada a técnica da análise fatorial aos 28 indicadores selecionados e às 359 unidades de observação - microrregiões, em nível nacional. 
39. Ano 40, no 3/4, julho - dezembro de 1978, p. 52 - 130.

Autor: Rivaldo Pinto de Gusmão; Olindina Vianna Mesquita. Colaboradores: Luiz Alberto Cerqueira do Nascimento; Edna Oliveira Barreto (Grupo de Trabalho de Difusão de Inovações - IPGH - Presidente: Pedro Pinchas Geiger).

Título: Difusão da Infra-Estrutura de Armazenagem e suas Vinculações com a Atividade Agrária no Noroeste do Rio Grande do Sul.

Conforme explicitado no texto, "o trabalho que se segue é um resultado de atividades desenvolvidas a partir da implantação do Projeto Especial no 74-014-04 do Instituto Pan-Americano de Geografia e História e que contou com o apoio do IBGE" (p. 52).

O objetivo do mesmo é o de contribuir para a propagação de conhecimentos relativos à teoria da difusão de inovações, especialmente na América Latina, através do preparo de documentos conceituais e metodológicos, bem como de documentos sobre a aplicação empírica destes conceitos e métodos. "Somente a aplicação da teoria a estudos de caso poderá fornecer uma avaliação sobre o papel da difusão de inovações, entendida em um sentido muito amplo, não se restringindo às inovações tecnológicas dentro de uma atividade já estabelecida, para o desenvolvimento".

Utilizaram-se os dados dos Censos Agropecuários do IBGE, em 1960 e 1970, tendo por base a análise fatorial, aplicando ao Rio Grande do Sul e mais especificamente ao Noroeste.

\section{Ano 40, no 3/4, julho - dezembro de 1978, p. 233 - 247.}

Autor: Rolf Wesche (Professor da Universidade de Ottawa, Canadá).

Título: A Moderna Ocupação Agrícola em Rondônia.

Como aponta Wesche, "o interesse popular e científico pelo desenvolvimento agrícola da Amazônia brasileira concentrou-se em projetos de colonização governamental ao longo da rodovia Transamazônica e em grandes projetos agropecuários no norte de Mato Grosso, norte de Goiás e leste do Pará. Enquanto isso, o território Federal de Rondônia recebeu muito pouca atenção, embora esteja entre os setores mais dinâmicos da região amazônica brasileira. Este dinamismo pode ser atribuído ao fato de que Rondônia, entre as principais unidades políticas da Amazônia clássica, é a que tem maior acesso ao sul e sudeste brasileiros já desenvolvidos, onde se origina o impulso de desenvolvimento amazônico. Este território é, sob vários aspectos, uma extensão longínqua da fronteira agrícola progressiva do sul do Brasil”.

Posto isto, o intento do autor é apresentar a moderna ocupação agrícola em Rondônia, tendo por base o tamanho de propriedade e uso da terra, identificando um padrão agrícola mais complexo que o da maioria das outras áreas da Amazônia. 


\section{Ano 42, no 1, janeiro - março de 1980, p. 3 - 30 .}

Autor: Solange Tietzmann Silva (Geógrafa do IBGE).

Título: Os Estudos de Classificação na Agricultura: uma revisão.

Como expressa Silva (p. 3), "no estudo geográfico da agricultura, a abordagem tradicional privilegiava a distribuição espacial da produção agrícola e dos rebanhos. Durante as décadas de 1920 e 1930, o enfoque preferencial transferiu-se desse estudo de produtos individuais para estudos de identificação de áreas, assumindo, então, caráter classificatório, embora a abordagem regional ao estudo da agricultura retroceda ao século XIX.

Entretanto, a abordagem da classificação na agricultura, apesar da atenção que o tema tem recebido por parte dos pesquisadores; e mais recentemente, do interesse que tem despertado não só para geógrafos, como para economistas e sociólogos rurais, tem se ressentido, de um modo geral, da falta de apoio de uma teoria que possa elucidar os problemas ligados aos critérios de definição de áreas e à explicação das variações nelas existentes. Diversos têm sido os critérios usados para, em função da grande variação espacial da atividade agrária, chegar à definição de áreas em agricultura: critérios físicos - em uma abordagem mais tradicional - e/ou sócio econômicos".

Concluindo, Silva enfatiza que a grande diversidade de critérios utilizados nos esquemas classificatórios em agricultura, e o interesse crescente em uma abordagem sintética da agricultura levaram a União Geográfica Internacional a criar, em 1964, a Comissão de Tipologia Agrícola, com o objetivo de tentar solucionar o complexo problema da classificação em agricultura.

\section{Ano 42, no 4, outubro - dezembro de 1980, p. 885 - 896.}

Autor: Lígia Celoria Poltroniéri (Professora Assistente. Departamento de Geografia e Planejamento do Instituto de Geociências e Ciências Exatas da UNESP - Campus de Rio Claro)

Título: Aspectos Sociais, Fundiários e de Modernização de Agricultura Paulista entre 1940 e 1970.

O presente artigo apresenta uma análise da dinâmica da agricultura paulista no que se refere aos atributos sociais, fundiários e de modernização da atividade no período de 1940 a 1970.

Poltroniéri estruturou o texto em três partes: 1. Características da Evolução da Ocupação do Espaço; 2. O Comportamento dos Atributos Sociais, de Uso do Solo e de Mão-de-obra; 3. A Dinâmica dos Principais Atributos Agrícolas.

Utiliza, como fontes de informação, dados do Departamento de Estatística do Estado de São Paulo (1954); da Secretaria de Agricultura do Estado de São Paulo Instituto de Economia Agrícola (1972); e os Recenseamentos Gerais do Brasil - 1940, 1950,1960 e 1970. 


\section{Ano 43, $n^{0} 1$, janeiro - março de 1981, p. 3 - 45.}

Autor: Adhemar Ribeiro Romeiro; Fernando José Abrantes.

Título: Meio Ambiente e Modernização Agrícola.

Hoje, na sociedade brasileira, há uma crença já bastante difundida sobre o papelchave que estaria reservado à agricultura na solução de quase todos os problemas graves em que se debate o país: inflação, desequilíbrio do balanço de pagamentos e o problema energético. A expectativa dos gestores da política econômica é de que, através de estímulos adequados, seria possível aumentar significativamente a produção agropecuária do país, em um prazo relativamente curto, gerando excedentes suficientes para atender a um aumento de oferta de alimentos para o mercado interno, um aumento das exportações e alternativas energéticas baseadas em fontes renováveis.

A ideia defendida pelos autores é de desenvolver uma pesquisa que vise a estudar o impacto desta ênfase no setor da agricultura sobre o meio ambiente - uma das linhas de preocupação também presentes no III PND - não apenas em uma perspectiva descritiva do fenômeno, mas também em outra que busque desvendar o mecanismo econômico de funcionamento da agricultura moderna.

Os autores ainda apontam: "Esta postura analítica passa pela necessidade de se pensar teoricamente, entre outros fatores, as relações entre agricultura e indústria, chave para a compreensão da adoção e reprodução de determinado padrão de utilização do solo rural e, por decorrência, dos efeitos deste sobre o meio ambiente".

\section{Ano 43, no 3, julho - setembro de 1981, p. 419 - 447.}

Autor: Rivaldo Pinto de Gusmão; Olindina Vianna Mesquita.

Título: Estrutura Espacial do Desenvolvimento Rural na Região do Cerrado (Transcrito da Região do Cerrado - Uma Caracterização do Desenvolvimento do Espaço Rural IBGE, 1979).

Ao se adotar, como apontam os autores, a concepção de que o desenvolvimento rural deve ser encarado não só como o desenvolvimento das atividades agrárias, mas também como a melhoria das condições de vida da população rural, segue-se, neste estudo, uma diretriz abrangente de consideração do espaço rural; na qual se considera a modernização das atividades agrárias, a melhoria das condições de bem-estar da população rural e as características infra-estruturais de apoio à agricultura.

A análise integradora dessas diferentes ordens de aspectos do espaço rural permitirá identificar as principais dimensões que diferenciam o desenvolvimento rural na "Região do Cerrado".

Quanto à metodologia para identificação das estruturas diferenciadoras do espaço rural na região em tela, foi utilizada a técnica multivariada da análise fatorial.

45. Ano 44, no 1, janeiro - março de 1982, p. 3 - 49.

Geo UERJ - Ano 14, nº 23, v. 2, $2^{\circ}$ semestre de 2012 p. 552-587

ISSN: 1415-7543 E-ISSN: 1981-9021

http://www.e-publicacoes.uerj.br/index.php/geouerj 
Autor: Maristella de Azevedo Brito; Olindina Vianna Mesquita.

Título: Expansão Espacial e Modernização da Agricultura Brasileira no Período 1970 1975.

Este trabalho insere-se no Programa de Pesquisa sobre evolução da agricultura brasileira, desenvolvido na Divisão de Estudos Rurais do Departamento de Estudos Geográficos da Fundação IBGE (p. 3).

O objetivo é identificar espaços caracterizados por diferentes formas de crescimento da agropecuária, e a ideia que norteou sua elaboração, como apontaram as autoras, foi a de que pudesse "se constituir em quadro de referência para a seleção de áreas-tipo a serem investigadas através de pesquisa direta".

Seu objetivo atrela-se às grandes transformações ocorridas no espaço agrário na década de 1970, as quais contribuíram para gerar ou agravar problemas de tal importância, pelo impacto sobre o conjunto da população, que sua discussão extravasou a esfera acadêmica, atingindo os meios de comunicação de massa.

Foram utilizados dados estatísticos dos Censos Agropecuários 1970 - 1975 IBGE para respaldar a base teórica selecionada.

$\mathrm{O}$ artigo apresenta-se estruturado em quatro partes. 1. Aspectos da Evolução da Agricultura a partir de 1950; 2. Formas de Crescimento da Agricultura; 3. Avaliação das Formas de Crescimento da Agricultura; 4. Tendências e Impasses na Evolução da Agricultura.

\section{Ano 44, no 2, abril - junho de 1982, p. 191 - 261.}

Autor: Maria do Socorro Brito; Solange Tietzmann Silva.

Título: O Papel da Pequena Produção na Agricultura Brasileira.

Como aponta Brito e Silva, "nas abordagens a estudos da agricultura brasileira, alguns aspectos emergem como os mais relevantes para qualificar a problemática que envolve esta atividade primária. Estes aspectos, que se tornam, então, alvo de uma apreciação mais profunda, devem ser vistos tomando-se em consideração a sua dimensão espacial, e são eles a estrutura fundiária, as relações de produção, o processo de modernização da agricultura e as relações da agricultura com o setor urbanoindustrial" (p. 191).

Para dar conta desta problemática, foram utilizadas informações estatísticas do Censo Agropecuário de 1975, por microrregiões homogêneas.

$\mathrm{O}$ artigo encontra-se estruturado em sete partes: 1. Introdução; 1.1. Quadro Técnico de Referência; 1.2. As áreas de pesquisa; 2. O quadro agrário; 3. A composição da mão-de-obra; 4. Características da produção; 5. A intensidade da agricultura; 6. A comercialização da produção; 7. Considerações finais.

47. Ano 45, $n^{0}$ 1, janeiro - março de 1983, p. 3 - 50.

Geo UERJ - Ano 14, nº. 23, v. 2, $2^{\circ}$ semestre de 2012 p. 552-587

ISSN: 1415-7543 E-ISSN: 1981-9021

http://www.e-publicacoes.uerj.br/index.php/geouerj 
Autor: Dora Rodrigues Hees.

Título: Transformações Técnicas e Relações de Trabalho na Agricultura Brasileira.

Segundo Hees (p. 3) "o artigo constitui a primeira parte de um trabalho mais amplo, que focaliza as transformações da mão-de-obra na agricultura brasileira no período 1970 - 1975, partindo-se dos pressupostos que as transformações que se vêm processando na agricultura brasileira, em conseqüência da maior capitalização de suas atividades, têm repercutido diretamente sobre as relações de trabalho no campo, o que torna a situação dos trabalhadores rurais uma das questões mais importantes no âmbito das atividades agrárias. Este problema é constatado, principalmente, ao se observarem alterações, na primeira metade da década de 70 , quer na composição da mão-de-obra rural, quer no grau de absorção desse contingente de força de trabalho agrícola, tendo por referência as microrregiões homogêneas delimitadas pelo IBGE.

Para dar conta da problemática e do objetivo apresentados, Hees estruturou seu artigo em duas partes, a saber: 1. Considerações teórico-metodológicas; 2. Alterações nas relações de trabalho em áreas de nível mais elevado de modernização.

\section{Ano 45, no 2, abril - junho de 1983, p. 155 - 204.}

Autor: Luiz Sérgio Pires Guimarães (Geógrafo da Divisão de Estudos Rurais DEGEO/SUEGE/DT/IBGE).

Título: Transformações Técnicas e Relações de Trabalho na Agricultura Brasileira em Áreas de Baixo Nível de Modernização.

O artigo desenvolvido por Guimarães constitui a segunda parte do trabalho sobre as transformações da mão-de-obra na agricultura brasileira, fundamentado na seguinte problemática, como aponta o autor: "ao se analisar as transformações havidas na composição da mão-de-obra rural no período 1970 / 1975, em conseqüência da expansão e/ou intensificação do capitalismo no campo, é preciso se ter em conta que este processo não incorpora o espaço rural brasileiro de modo uniforme e homogêneo, mas sim que ele incide sobre as diversas regiões agrícolas, sob formas diversas".

Para dar conta desta problemática, a metodologia de pesquisa pautou-se na análise de dados estatísticos dos censos agropecuários de 1970 e 1975 - IBGE, segundo o recorte espacial das microrregiões homogêneas definidas pelo IBGE.

$\mathrm{O}$ artigo encontra-se estruturado em quatro partes, a saber: 1 . Áreas de Pequena Variação na Estrutura de Mão-de-obra; 2. Áreas de Aumento de Trabalho Familiar; 3. Áreas de Aumento de Trabalho Assalariado; 4. Conclusão.

49. Ano 45, no 3 e 4, julho - dezembro de 1983, p. 263 - 309.

Autor: Ney Rodrigues Innocêncio e Tereza Maria Ramos de Oliveira (Técnicos da Divisão de Estudos Rurais DEGEO/SUEGE/DT/IBGE). 
Título: Transformações Técnicas e Relações de Trabalho na Agricultura Brasileira em Áreas de Nível Médio de Modernização.

Este artigo fez parte de um trabalho mais amplo que focaliza as transformações de mão-de-obra na agricultura brasileira no período 1970 - 1975.

Para tanto, os autores afirmam que as microrregiões homogêneas a serem estudadas nesta parte do trabalho são as que se encontram inseridas em um contexto em que a inserção do capitalismo se faz, não tanto via modernização, mas pela incorporação da área ao processo produtivo, correspondente ao Nordeste, Sudeste, Norte, CentroOeste e Sul.

A área em estudo foi a que apresentou nível intermediário quanto à incorporação de máquinas e insumos modernos ao processo de produção agrícola, no período de 1970 - 1975. Para tanto, os autores explicitam: "em que medida esse nível de modernização acarretou modificações na composição da mão-de-obra rural, nos produtores rurais e na estrutura fundiária" (p. 263).

O processo de modernização que vem ocorrendo na área em estudo é reflexo da própria maneira como se caracteriza o capitalismo agrícola em geral, isto é, apresentando uma multiplicidade de formas.

\section{Ano 45, no 3/4, julho - dezembro de 1983, p. 425 - 439.}

Autor: Claude Servolin (Transcrito de Cahiers de la Fondation Nationale des Sciences Politiques, 184 - Fundation Nationale des Sciences Politiques (Paris). Tradução de Sylvia Heller (CEDIT/DEDIT/DIRED).

Título: A Absorção da Agricultura no Modo de Produção Capitalista

Segundo Servolin, "desde o momento em que colocamos a questão da estrutura de classes do mundo agrícola, todas as respostas que lhe foram dadas levam evidentemente ao problema do destino econômico da agricultura na sociedade capitalista" (p. 425).

Desde logo, não restou dúvida, para nenhum economista, que a pequena produção individual, nascida da dissolução do modo de produção feudal, seria, cada vez mais, vítima de uma concentração capitalista. É testemunho disto a declaração muito conhecida de Quesnay segundo a qual "as terras utilizadas para a cultura de grãos fossem reunidas, tanto quanto possível, em grandes fazendas exploradas por fazendeiros ricos, porque há menos despesas com a manutenção e reparo de instalações e, em proporção, muito menos gastos e muito mais produto líquido nas grandes explorações que nas pequenas" (p. 425).

$\mathrm{O}$ artigo encontra-se estruturado em cinco partes: I. Uma Concentração "Irreversível"; II. ... E sem Cessar "Atrasada"; III. O Processo da Grande Produção; IV. Campesinato Parcelar e Pequena Produção Mercantil; V. Pequena Produção Mercantil e Modo de Produção Capitalista. 


\section{Ano 46, no 3 e 4, julho - dezembro de 1984, p. 425 - 550.}

Autor: Adma Hamman de Figueiredo; Olindina Vianna Mesquita; Solange Tietzmann Silva (Geógrafas da Divisão de Estudos Rurais. Dep. Geografia. IBGE).

Título: O Impacto Desigual da Modernização da Agricultura no Oeste do Paraná.

Esta pesquisa insere-se num contexto de compreensão da organização atual do espaço agrário nacional, no qual algumas áreas emergiram como centro de uma problemática mais ampla, qual seja a do processo de modernização acelerado que marcou a década de 70. Em uma perspectiva de entendimento desse processo, em escala regional, foi selecionado, como campo de investigação, o Oeste Paranaense, que se constitui num dos espaços do país mais intensamente submetidos a transformações na base técnica da produção.

A escolha dessa região respaldou-se em estudo anterior, publicado na R.B.G. ano $44, n^{\circ} 1$, elaborado a partir de dados censitários agropecuários que, ao focalizar as formas básicas de crescimento da agricultura no país, no período 1970 - 1975, apontou o Oeste Paranaense como uma das regiões de mais acentuada mudança nas características técnico-produtivas, acompanhada de expansão do espaço agrário.

\section{Ano 49, no 1, janeiro - março de 1987, p. 3 - 10.}

Autor: Olindina Vianna Mesquita; Solange Tietzmann Silva (Analistas Especializados em Geografia - FIBGE).

Título: A Evolução da Agricultura Brasileira na Década de 70.

O artigo trata de apresentar o quadro geral da agricultura brasileira na década de 70 e, neste sentido, as autoras explicitam: "a acentuação do crescimento horizontal e a intensificação do processo de modernização que marcaram a agricultura no período 1970 - 1980 conferiram uma posição peculiar, no quadro da evolução da agricultura brasileira, a esse período" (p. 3). Com efeito, na década de 70, ocorreu uma extraordinária expansão da área dos estabelecimentos, especialmente nas Regiões Norte, Centro-Oeste e Nordeste, como resultado da melhoria crescente das condições de acessibilidade a espaços fracamente ocupados, dos incentivos fiscais e financeiros e, ainda, da perspectiva do empreendimento agropecuário como alternativa de investimento.

Paralelamente a essa ampliação do espaço agrário, verificou-se também, no país, nos anos 70, um processo muito acelerado de modernização das atividades agrárias, mais acentuado nas regiões Sul e Sudeste, e sustentado, basicamente, pela política de crédito rural implantada no final da década de 60.

53. Ano 49, no 1, janeiro - março de 1987, p. 11 - 46.

Autor: Maria Socorro Brito; Mitiko Yanaga Une (Analistas Especializados em Geografia. FIBGE). 
Título: A Evolução da Agricultura na Região Norte na Década de 70.

A Amazônia, tradicionalmente uma região de extrativismo, passou, ao longo dos anos 70, a ter redefinido o seu papel na organização espacial do país. Esta nova ótica alicerçava-se em uma política governamental que objetivava integrar esta região ao sistema econômico brasileiro. A estratégia do governo centrava-se na ocupação produtiva do território que, através do modelo de Enclave de Exportação, procurava incentivar o aproveitamento integrado das potencialidades regionais, incluindo, para tanto, as indústrias de transformação de produtos primários, abrangendo os de madeira, borracha, têxteis e projetos minerais, agropecuários e agroindustriais.

Estas transformações ensejavam uma mudança na malha fundiária como resultante da introdução de grandes estabelecimentos agropecuários, bem como da reprodução dos pequenos, relacionados à ocupação espontânea e à colonização dirigida, que estabeleceu o assentamento do módulo familiar de 100 hectares.

Esta nova estruturação do espaço veio acarretar mudanças na economia da região, até então voltada para o mercado internacional e baseada fundamentalmente no aproveitamento dos recursos naturais.

\section{Ano 49, $n^{0}$ 1, janeiro - março de 1987, p. 47 - 106.}

Autor: Marília de Saldanha da G. L. Chmatalik ${ }^{1}$; Maristella de Azevedo Brito²; Tereza Maria Ramos de Oliveira ${ }^{3}$ (1. Analistas Especializados: em Economia; 2. em Geografia; 3. em Sociologia. FIBGE).

Título: A Evolução da Agricultura na Região Nordeste na Década de 70.

A evolução da agricultura brasileira, na década de 70, foi profundamente influenciada pelas medidas de política governamental, adotadas a partir de 1964 e voltadas para a capitalização do setor primário da economia. Assim, durante a segunda metade da década de $60_{2}$ e sobretudo nos anos 70, verificou-se a progressiva inserção da agricultura dentro do modelo de desenvolvimento orientando pelo grande capital monopolista. Nesse modelo, cumpria à agricultura o papel de contribuir com divisas para a expansão industrial e de fornecer alimentos de baixo custo às populações urbanas.

Neste contexto, as autoras estruturaram o artigo em duas partes. A primeira aborda a caracterização do espaço agrário nordestino, enquanto na segunda parte são analisadas as transformações da agricultura da região selecionada, durante a década de 70, tendo por recorte as microrregiões homogêneas e, como fonte de informações censitárias, a Sinopse do Censo Agropecuário de 1980 - IBGE, além dos Censos Agropecuários.

55. Ano 49, no 1, janeiro - março de 1987, p. 107 - 157.

Autor: Luiz Sergio Pires Guimarães; Ney Rodrigues Innocencio (Analistas Especializados em Geografia. FIBGE).

Geo UERJ - Ano 14, nº 23, v. 2, $2^{\circ}$ semestre de 2012 p. 552-587

ISSN: 1415-7543 E-ISSN: 1981-9021

http://www.e-publicacoes.uerj.br/index.php/geouerj 
Título: A Evolução da Agricultura na Região Sudeste na Década de 70.

Considerando-se o nível de desenvolvimento do seu processo de produção, o Sudeste apresenta uma organização espacial relativamente uniforme e se constitui no centro hegemônico das relações que estruturam a atual organização regional do país. Tal posição tem se consolidado ao longo do tempo, na medida em que os interesses do capital urbano sobrepujam aqueles relativos aos do capital rural. Ressalte-se, porém, que este desenvolvimento do capitalismo urbano não exclui o setor rural, mas antes o integra de forma definitiva através de um processo de expansão e intensificação do capital no campo, refletido sobremaneira no número crescente de explorações agrárias em caráter nitidamente empresarial.

Para dar conta desta problemática, Guimarães e Innocêncio estruturaram o artigo em quatro partes. A primeira aborda os aspectos gerais da organização agrária no período 1950 - 1970. A segunda parte trata da evolução da agricultura brasileira na década de 70; e por fim, na terceira parte, são analisadas as transformações na organização agrária do Sudeste.

Quanto às informações estatísticas, foram utilizados o Censo Agropecuário do Brasil 1970 e Sinopse Preliminar do Censo Agropecuário de 1980 - IBGE, tendo por escala de análise as microrregiões homogêneas.

\section{Ano 49, no 1, janeiro - março de 1987, p. 159 - 195.}

Autor: Olindina Vianna Mesquita; Solange Tietzmann Silva (Analistas Especializados em Geografia. FIBGE).

Título: A Evolução da Agricultura na Região Sul na Década de 70.

A Região Sul que vinha se caracterizando, até o final da década de 60, pela sua condição de produtora de alimentos para o mercado interno, teve alterada, ao longo da década de 70, a sua posição na divisão espacial do trabalho, uma vez que nela se processou grande expansão da lavoura comercial da soja, no âmbito dos estímulos oficiais à produção para exportação. Com efeito, as medidas de política agrícola, inseridas num contexto mais amplo do processo de acumulação de capital, ditado por interesses nacionais e transnacionais, influíram, de forma decisiva, na agricultura regional que, em alguns anos, teve modificado o seu patamar técnico-produtivo.

Posto isto, as autoras estruturam o texto em três partes. Na primeira, analisam aspectos da reorganização agrária regional; na segunda, tratam da diferenciação espacial de elementos de transformação da agricultura; e na terceira parte, são discutidas as formas de crescimento da agricultura.

Quanto às informações estatísticas, foram utilizados o Censo Agropecuário 1970 e Sinopse Preliminar do Censo Agropecuário de 1980 - IBGE; além da Produção Agrícola Municipal (PAM), 1980 - IBGE.

57. Ano 49, no 1, janeiro - março de 1987, p. 197 - 257.

Geo UERJ - Ano 14, no. 23, v. 2, $2^{\circ}$ semestre de 2012 p. 552-587

ISSN: 1415-7543 E-ISSN: 1981-9021

http://www.e-publicacoes.uerj.br/index.php/geouerj 
Autor: Dora Rodrigues Hees; Maria Elisabeth de Paiva Corrêa de Sá; Tereza Coni Aguiar (Analistas Especializados em Geografia. FIBGE).

Título: A Evolução da Agricultura na Região Centro-Oeste na Década de 70.

Para a compreensão das transformações da agropecuária que se desencadearam no Centro-Oeste, ao longo dos anos 70, procurar-se-á situar a mesma em um contexto de criação de políticas governamentais, voltadas para a agricultura. Assim, será considerado seu posicionamento como área de grande potencial para a expansão da atividade agropecuária, em uma fase de desenvolvimento econômico nacional em que são canalizados recursos para a agricultura, a fim de que esta atividade possa concorrer para o crescimento urbano-industrial e fazer frente a compromissos assumidos pelo Brasil no mercado externo.

Nesse sentido, como apontam Hees, Corrêa de Sá e Aguiar, será realizado um estudo evolutivo da organização do quadro agrário regional, na década de 70 , no qual se buscará compreender os diversos arranjos espaciais que emergiram do impacto dessa nova orientação governamental e as modificações que ocorreram no processo de produção agropecuária.

Para dar conta do objetivo e da problemática construída, o artigo foi estruturado em três partes: a primeira trata do papel do Estado vinculado à expansão agrícola e impasses sociais; a segunda parte caracteriza as principais transformações do quadro agrário na década de 70; e por fim, na terceira, são apresentadas as diferenciações espaciais da agropecuária no recorte espacial selecionado, Centro-Oeste, utilizando-se as Microrregiões Homogêneas.

\section{Ano 49, no 3, julho - setembro de 1987, p. 139 - 161.}

Autor: Maristella de Azevedo Brito (Analista Especializado em Geografia. FIBGE).

Título: Questões associadas à Evolução Recente da Agricultura Brasileira.

Brito expressa: "na reorganização do espaço brasileiro, nas duas últimas décadas, tiveram papel muito significativo as transformações que se processaram na agricultura, envolvendo a integração de extensas áreas escassamente ocupadas à economia nacional, a modernização acentuada do processo produtivo adotado em algumas lavouras, a ampliação e diversificação da produção agrícola do país. Entretanto, no decorrer desse processo de crescimento da agricultura, agravaram-se contradições que conduziram à retomada da discussão sobre a questão agrária - como um dos grandes temas de interesse nacional - agora encarada sob o enfoque bastante diverso do que predominou nos acirrados debates que se travaram no final dos anos $50 \mathrm{e}$ início dos anos 60. Aquela época, um dos argumentos que assumiram maior destaque nas discussões era o de que o atraso da agricultura brasileira se constituía em obstáculo ao desenvolvimento econômico do país, especialmente ao avanço econômico do país, especialmente ao avanço de seu crescimento industrial" (p. 139),

Tais processos de transformações ocorridos na agropecuária influenciaram em problemas relativos à estagnação de algumas lavouras e, neste sentido, a autora elabora uma análise da distribuição espacial de algumas das principais lavouras do país,

Geo UERJ - Ano 14, nº 23 , v. 2, $2^{\circ}$ semestre de 2012 p. 552-587

ISSN: 1415-7543 E-ISSN: 1981-9021

http://www.e-publicacoes.uerj.br/index.php/geouerj 
reunidas em três grupos distintos: o dos produtos tradicionais de exportação, o dos produtos alimentares básicos e o dos produtos "exportáveis".

Posto isto, Brito estruturou seu texto em quatro partes. A primeira, intitulada Transformações da Agricultura Brasileira a partir dos anos 60; a segunda parte, Padrão de Distribuição Espacial e Evolução das lavouras; a terceira, Diferenciação Espacial da Organização Agrária; a quarta, Problemas Relacionados à Evolução Recente da Agricultura, tendo por operacionalização a utilização da Produção Agrícola Municipal de 1976 e 1984, IBGE, e do Censo Agropecuário 1970, 1975 e 1980, IBGE, por Microrregiões Homogêneas.

\section{Ano 50, $n^{\circ} 1$, janeiro - março de 1988, p. 41 - 60.}

Autor: Dora Rodrigues Hes; Tereza Coni Aguiar (Analistas Especializados em Geografia. FIBGE).

Título: A Apropriação do Espaço Agrário pela Pecuária no Centro-Oeste.

A expansão da pecuária no Brasil não é um fenômeno recente, ao contrário, esta atividade sempre teve papel fundamental na ampliação do espaço agrário brasileiro. Porém, foi a partir dos anos sessenta que a pecuária apresentou um ritmo mais acentuado de crescimento no país, ao mesmo tempo em que se alteraram os mecanismos que determinam a sua reprodução. Uma série de medidas governamentais foi criada em meados da década de 60, com a finalidade de expandir a ocupação de vastas áreas do Território Nacional com esta atividade; normalmente, como substituição da lavoura. E, no caso das áreas de expansão da fronteira, grandes extensões de áreas exercem repercussões sobre a organização do espaço agrário e acarretam consequências sociais. Assim, como enfatizam as autoras, é adequado falar em pecuarização, em um sentido mais amplo, e não simplesmente em expansão da pecuária.

As autoras ainda apontam que "a hegemonia da atividade criatória associada à fraca diversificação das atividades agrícolas contribuem para a falta de perspectiva das populações locais, no sentido de sua prosperidade social".

Posto isto, Hees e Aguiar estruturam o texto em três partes: 1. Condições da Reprodução da Agropecuária no Espaço Agrário; 2. A Expansão da Pecuária e o seu Sistema de Produção; e 3. A Concentração da Terra e as Relações Sociais de Produção; utilizando-se de informações estatísticas da FGV, CACEX, CONDEPE, referentes a 1984; Censo Agropecuário, 1970 e 1980, IBGE, a partir das Microrregiões Homogêneas.

\section{QUARTO PERÍODO - 1991-2005}

\section{Ano 53, no 3, julho - setembro de 1991, p. 149 - 159.}

Autor: Ignez C. B. Ferreira (Professora da Universidade de Brasília - UNB) 


\section{Título: A Gestão do Espaço Agrário}

O meio rural vem sendo atingido, nas últimas décadas, por um processo de grande magnitude e fortes implicações territoriais, que redefiniu o espaço agrário, envolvendo todas as regiões do país, segundo Ferreira. Facilmente se reconhece que a paisagem rural brasileira se modificou em pouco tempo. A agricultura assumiu novas funções interligadas à indústria e ao setor financeiro, inovações tecnológicas foram introduzidas na produção e uma nova dinâmica rural-urbana se estabeleceu. Por outro lado, a fronteira agrícola se ampliou extraordinariamente -83 milhões de hectares ${ }_{2}$ de 1970 a 1985, o que significou um acréscimo de 30\%, incorporando $10 \%$ do território nacional à área total dos estabelecimentos agropecuários. As lavouras também se expandiram e sua superfície cresceu 54\% nesse período, aumentando em 18 milhões o espaço dessa produção. Ao mesmo tempo, as pastagens se estenderam por mais de 45 milhões de hectares, com um aumento em área de $150 \%$.

Neste contexto, Ferreira expõe que "o presente trabalho procura analisar o comportamento espacial do aludido processo em suas duas dimensões: expansão territorial e modernização, buscando a atuação dos elementos da gestão do território" (p. 150).

As análises se baseiam nos dados estatísticos oficiais abrangendo o período 1970 - 1985; e as generalizações decorrem de estudos de casos realizados anteriormente.

\section{Ano 54, no 2, abril - junho de 1992, p. 27 - 55.}

Autor: Lia Machado (Geógrafa, Professora Adjunta do Dep. de Geografia UFRJ: Pesquisadora do Conselho Nacional de Desenvolvimento Científico e Tecnológico CNPq).

Título: A Fronteira Agrícola na Amazônia Brasileira.

Como aponta Machado, "o propósito deste trabalho é destacar os principais elementos que possibilitem a compreensão do processo de modelação de espaços agrários na Amazônia brasileira, atentando, de imediato para o seguinte: a) a ocupação agrícola se processa de forma descontínua no espaço, configurando um padrão de 'manchas', à margem dos rios e vias de penetração, e no entorno de cidades e grandes projetos de exploração hidrelétrica e mineral; b) apesar do crescimento recente da produção agrícola, ela não participa de modo significativo da oferta agrícola a nível nacional" (p. 28).

$\mathrm{O}$ artigo encontra-se estruturado em uma primeira parte "dedicada ao rastreamento histórico de conceitos como 'fronteira', 'frente' e 'pioneiro', e do uso que deles foram utilizados no Brasil. Na segunda parte apresentam-se as principais características do processo de assentamento agrícola na região amazônica brasileira, organizadas em torno de eixos temáticos" (p. 28).

62. Ano 54, $n^{0}$ 4, outubro - dezembro de 1992, p. 1 - 98.

Geo UERJ - Ano 14, nº. 23, v. 2, $2^{\circ}$ semestre de 2012 p. 552-587

ISSN: 1415-7543 E-ISSN: 1981-9021

http://www.e-publicacoes.uerj.br/index.php/geouerj 
Autor: Geraldo Müller (Pesquisador do Dep. de Planejamento Regional do Instituto de Geociências e Ciências Exatas. Universidade Estadual Paulista (UNESP), Campus de Rio Claro [SP]).

Título: O Agrário Verde-Amarelo, Hoje e Amanhã.

O artigo de Müller levanta a problemática concernente ao ajustamento das contas públicas como um dos elementos nucleares das pré-condições para que seja restabelecido o papel desenvolvimentista do Estado. $\mathrm{O}$ outro elemento, agora diretamente atrelado a este, por causa da forma democrática associada à retomada do crescimento, é de caráter sócio-político: a participação dos diversos segmentos sociais na retomada do crescimento econômico, que objetiva não somente romper o bloqueio ao crescimento, mas efetivamente superar o subdesenvolvimento. $\mathrm{O}$ velho dilema, como aponta Müller, entre acumulação e distribuição reaparece numa situação de profunda crise nacional e de grandes mudanças tecno-produtivo-comerciais e sócio-políticoculturais também no âmbito internacional.

Para travar tal discussão e diálogo, Müller estruturou seu artigo em: 1.O Brasil no Início dos Anos 90; 2. Situação Internacional e Crise Nacional; 3. Privação de Poder e Pobreza; 4. Heranças Agrárias: Renúncia e Aceitação; 5. Os Resultados da Modernização Agrária; 6. Produção, Produtores e Regiões; 7. Tendências.

\section{Ano 57, no 4, outubro - dezembro de 1995, p. 37 - 48.}

Autor: Angélica Alves Magnago; Roberto de Castro Nóbrega Barrucho; Suzi de Mattos; Tereza Coni (Geógrafos do Dep. de Geografia. Diretoria de Geociências. IBGE).

Título: A Modernização da Agricultura no Entorno do Distrito Federal e a questão ambiental.

O objetivo do trabalho é identificar as transformações do espaço rural no Entorno do Distrito Federal, analisando os principais problemas e repercussões no meio ambiente.

Tal objetivo atrela-se à problemática vigente, englobando a Microrregião Geográfica do Entorno de Brasília, constituída por 16 municípios adjacentes ao Distrito Federal, e que se apresenta vinculado a um conjunto de elementos físicos muito diversificados, no qual se estruturam as relações homem/natureza. A história da ocupação do território é responsável pelos atuais padrões de utilização do espaço na área daquele Entorno.

Os autores, para atingirem o objetivo proposto, apresentaram a seguinte estrutura de texto: 1. Efeitos de urbanização de Brasília sobre as áreas rurais do entorno; 2. Modernização agrícola e transformações na agropecuária e; 3. Problemas ambientais. 


\section{Ano 58, no 1/4, janeiro - dezembro de 1996, p. 121 - 136.}

Autor: Daniela Coswig Kalikoski; Milton L. Asmus (Geógrafa, mestranda do Curso de Pós-Graduação em Educação Ambiental Dep. de Oceanografia da Fundação Universidade Federal do Rio Grande - FURG; Professor Titular do Dep. de Oceanografia da Fundação Universidade Federal do Rio Grande - FURG - Trabalho parcialmente financiado pela FINEP).

Título: Análise Sistêmica de Ambientes Agrícolas na Região Costeira Sul-brasileira.

Segundo os autores, o trabalho lida com aspectos ambientais e socioeconômicos de áreas agrícolas da região costeira sul-brasileira, aplicando técnicas de modelagem ecológica. Para tal, selecionou-se como área de estudo o município de São Lourenço do Sul, no Rio Grande do Sul. O município possui uma população predominantemente rural, fazendo com que seu setor primário apresente grande relevância para a região. Como indicam Kalikoski e Asmus, o trabalho teve como objetivos: "1. Identificar tipos dominantes de sistemas agrícolas no município selecionado; 2. Identificar os componentes, processos, controladores externos e internos, e principais fontes energéticas dos agroecossistemas; elaborar modelos ecológicos das atividades agrícolas de base familiar e do tipo agro business; e 4. Fornecer, através da caracterização ambiental e modelagem, subsídios para futuras ações de mitigação, conservação e de planejamento".

Através do conhecimento assim adquirido, poder-se-á colaborar na obtenção de informações voltadas a um desenvolvimento sustentável para a área selecionada, tendo em conta sua atual má distribuição de recursos e sua elevada demanda social.

\section{Ano 59, no 2, julho - dezembro de 2005, p. 83 - 97.}

Autor: Gláucio José Marafon; Miguel Angelo Ribeiro (Professores do Instituto de Geografia/UERJ - Campus Maracanã).

Título: Agricultura Familiar, Pluriatividade e Turismo Rural: reflexões a partir do território fluminense.

Segundo Marafon e Ribeiro, o território fluminense encontra-se marcado por um intenso processo de urbanização, que tem provocado profundas transformações sócioespaciais. Entre elas, destacamos as atividades associadas ao turismo rural contemporâneo, com a proliferação de hotéis-fazenda, spas, pousadas, e casas de segunda residência, assim como a manutenção, e até mesmo o aumento, da produção familiar. A proliferação dessas atividades possibilitou, aos produtores familiares, a inserção em atividades não-agrícolas e, consequentemente, o aumento da renda familiar.

Destarte, o objetivo desse ensaio é o de apresentar algumas características sobre as abordagens da produção familiar e suas estratégicas de sobrevivência, através de empregos agrícolas ou não-agrícolas, e o papel que o turismo rural vem desempenhando nesse processo. Nossa reflexão está centrada a partir do território fluminense, resultado de nossas investigações sobre as transformações que estão ocorrendo em seu espaço rural. 


\section{Referências}

CASTRO, Anna Maria. Josué de Castro: arauto da paz. In: MARTINS, Paulo Emílio Mattos; MUNTEAL, Oswald. O Brasil em Evidência: a utopia de desenvolvimento. Rio de Janeiro: Ed. PUC-Rio; FGV, 2012, p. 20-4, 486p.

MARAFON, Glaucio José; RIBEIRO, Miguel Angelo. Os Estudos Agrários no âmbito da Geografia Oficial Brasileira: O Instituto Brasileiro de Geografia e Estatística (IBGE) e o periódico Revista Brasileira de Geografia (RBG) - 1940-2005, 2012 (Inédito).

Artigo encaminhado para publicação em setembro de 2012.

Artigo aceito para publicação em outubro de 2012 . 